\title{
TRADUÇÃO E HERMENÊUTICA
}

\author{
João Azenha Júnior!
}

STOLZE, Radegundis. Hermeneutisches Übersetzen. Linguistische Kategorien des Verstehens und Formulierens beim Übersetzen. Tübingen, Gunter Narr Verlag, 1992.

Em 1982, Radegundis Stolze apresentou à Faculdade de Neofilologia da Universidade de Heidelberg sua tese de doutoramento intitulada Modalitäten der Textrealisierung als Problem des Übersetzens (As modalidades da realização textual como problema de tra. dução). No mesmo ano, com algumas modificaçoes, a tese foi publicada com o título de Grundlagen der Textübersetzung (Fundamentos da tradução textual). Neste trabalho de 1982, Stolze define sua perspectiva para a observaçāo do processo de tradução e passa a ser, ao lado de Fritz Paepcke, um dos nomes representativos da chamada corrente hermenêutica dos estudos tradutológicos.
Fundamentais para a caracterização desse ângulo de observação são a noção de sentido (de um texto) e o trabalho de interpretação que o acesso ao sentido requer (do receptor de um texto). Nesse quadro, o texto é visto como uma "unidade de sentido supra-somativa" (1), isto $\dot{e}$, uma unidade passivel sim de decomposição em segmentos menores, mas cujo sentido global não se deriva da simples soma dos sentidos (isolados) de palavras e sentenças. A partir de uma tal concepção, apoiada nos conceitos da psicologia da gestalt, um texto, enquanto unidade complexa, aponta para "algo a mais" a ser desvendado pelo receptor a partir de um emaranhado complexo de relações que se estabelecem entre as unidades lingüisticas propriamente ditas, e entre elas $\mathrm{e}$ o contexto situacional e cultural, historicamente condicionado, dentro do qual o texto ocorre. Para Stolze, a "multiperspectivida- 
de" dos textos exige do receptor "um comportamento extremamente flexível, que procura compreender o todo do texto na visão conjunta dos seus diversos aspectos" (2).

Em Hermeneutisches Übersetzen. Linguistische Kategorien des Verstehens und Formulierens beim Übersetzen (Hermenêutica e tradução: categorias lingüisticas da interpretação e da formulação no processo de tradução), ainda sem tradução para o português, Radegundis Stolze dá continuidade às suas reflexões sobre tradução a partir desse exercício de hermenêutica, de interpretação de sentidos.

A partir de uma concepção de tradução "determinada pelo fator humano" (3), Stolze postula para os estudos de tradução mais do que o simples confronto entre produtos acabados - uma descrição do processo de tradução, entendido este como "processo de interação dirigida entre individuos anco. rados histórica e socialmente" (4). Para Stolze, a teoria da tradução deve ser uma reflexão sobre a prática, deve ser a descrição sistemática de uma prätica, e não a verificação de modelos previamente desen. volvidos. Nesse quadro insere-se o objetivo do livro: "refletir metodicamente sobre a prática, a fim de colocar à disposiçāo dos tradutores critérios que lhes possibilitem justificar suas escolhas no plano lingüistico" (5), para o que são acionados os instrumentos até então desenvolvidos pela pesquisa lingüistica e de disciplinas afins.

A fim de enfocar e descrever o processo de tradução no máximo possivel de sua abrangência, Stolze divide seu livro em três partes.

$\mathrm{Na}$ Parte A, "Aspectos da translação", são lançadas as bases do trabalho: 0 aspecto comunicativo - já que a atividade de tradução é vista sob a óptica da transmissão e da compreensão de mensagens entre pessoas -, a visão que se tem do tradutor propriate dito enquanto "indivíduo ancorado histórica e culturalmente", o conhecimento lingüístico como condição para a compreensão e a noção de "competência tradutória", que envolve aspectos tais como a acuidade idiomática, criatividade lingüistica, intuição, capacidade crítica de testar o próprio trabalho, experiencia, entre outros.

A Parte B, "As categorias da recepção", subdivide-se em Temática, Semântica e Léxico. No item "Temática" discutem-se, entre outros, a importância de se situarem os exemplares de textos como pré-condição para a compreensão, a questão da tipologia textual (diferenciação entre textos da linguagem comum e das linguagens técnicas) e aspectos concernentes à estruturação do texto e ao modo como eles influem na com. preensão. Em "Semântica" são enfocados, entre outros, os planos de isotopia, as cono. taçōes e redes associativas, e 0 aspecto multifuncional de lexemas. Em "Léxico" a tônica recai sobre a questão dos termos técnicos, sobre o "desenvolvimento cumulativo das denominações" e sobre a necessidade de se considerar a terminologia e os processos de normatização lingüistica a partir de uma perspectiva evolutiva, dinâmica.

Na Parte C, "As categorias da produção", o centro das atençōes são os aspectos envolvidos na produção do texto de chegada. Especial ênfase é dedicada aos aspectos pragmáticos envolvidos na tradução: a finalidade da traduçāo e suas (diferentes) implicaçōes no trabalho com textos de diferentes tipos, os efeitos do pano de fundo cultural $e$ as diferentes realidades materiais, a consideração dos diferentes registros de linguagem. Nesta parte são abordadas ainda as implicaçōes para a tradução dos estudos e do instrumental de análise estilística. Normas e convençōes que regem certos tipos de textos têm garantido seu espaço nesta discussão.

Assim apresentado em suas diretrizes, podemos dizer que um dos maiores méritos do presente livro está no instrumental que ele fornece ao tradutor-estudioso de tradu- 
ção, e mesmo ao estudante de tradução com algum trânsito pelos estudos da linguagem. Adaptado ao caso particular, tal instrumental permite ao tradutor - e nesse sentido vai ao encontro do objetivo a que a obra se propõe - justificar suas escolhas no plano lingüistico, isto $\dot{e}$, optar conscientemente pelos recursos lingüísticos e não lingüísticos que colocará a serviço da execução de seu objetivo de (re)produção textual. Conscientemente é aqui uma palavra-chave, pois a reflexão sobre o trabalho permite ao tradutor controlar a coerência no plano de tomada de decisões e tem conseqüências importantes para a defesa do texto produzido diante de eventuais criticas.

Dois outros pontos merecem consideração. Em primeiro lugar, a abrangência do córpus de textos usados para ilustrar as reflexōes desenvolvidas ao longo do livro: trata-se de exemplares que vāo da literatura à propaganda, passando por textos técnicos e documentos oficiais. Nesse sentido, o livro contribui para a busca de elementos comuns no tratamento de problemas de tradução em textos de diferentes tipologias. Em segundo, o espaço reservado no livro às conseqüencias que se podem tirar dessas reflexōes para a concepção de um modelo voltado para o ensino de tradução. E nesse sentido, uma tal contribuição é sempre muito bem-vinda, já que - ao menos entre nós - a didática da tradução não tem sido alvo de discussões mais sistemáticas.

\section{REFERÊNCIAS BIBLIOGRÁFICAS}

(1) STOLZE, Radegundis. Grundlagen der Textübersetzung. Heidelberg, Groos, 1982, p. 31.

(2) Idem, p. 32.

(3)

Hermeneutisches Übersetzen. Linguistische Kategorien des Verstehens und Formulierens beim Übersetzen. Tübingen, Narr, 1992, p. 13.

(4) Idem, ibidem.

(5) Idem, p. 14.

1. Professor assistente de Lingua e Literstura Alemã da FFLCH-USP.

2. De "Translation", termo Jiperönimo usado para abrigar as modalidades da traduçio (escrita) e da interpretaçāo (oral). 
